\title{
e-Lifestyle Confirmatory of Consumer Generation Z
}

\author{
Tony Wijaya ${ }^{1}$, Arum Darmawati ${ }^{2}$, Andreas M Kuncoro ${ }^{3}$ \\ Faculty of Economy, Universitas Negeri Yogyakarta \\ Yogyakarta, Indonesia
}

\begin{abstract}
The development of information technology has changed daily life patterns that tend towards digital. Differences across generations will result in understanding different behaviors and lifestyles, which are a challenge in this research. Lifestyle is needed in determining market segments of consumer behavior. Lifestyle understanding in Generation $Z$ is expected to provide valuable information in various fields of socio-economic life. These findings are expected to provide an overview for marketers targeting the market in this segment. Understanding lifestyles can be an ingredient in developing marketing strategies according to the intended segment, especially Generation $Z$, which has identified a lifestyle following information technology or digital development. The research aimed to confirm e-lifestyle factors among Generation $Z$, especially university students, as members of the academic environment's dominant academic community. Specifically, the aim is to identify the pattern of elifestyle formation in Generation $Z$, especially among students and the information or social media used by Generation $Z$. This type of research is a survey. This research was initiated through empirical field observations. The study population used in this study was university students in Yogyakarta-Indonesia. The sampling technique uses a simple random sampling technique. The data used are primary: the response given by research subjects related to e-lifestyle factors. Data was collected through a survey using a questionnaire. The data analysis technique in this study uses a Confirmatory Factor Analysis (CFA). The results showed that the motives that became the basis of elifestyle in the $Z$ generation corresponded to four factors, namely, e-activities, e-interests, e-opinions, and e-values. Information or social media are often used by Generation $Z$, namely, Instagram, Youtube, Line, Facebook, Twitter, Discard, Pinterest, Spotify, and Telegram. The purpose of using the information or social media is communication, entertainment, consumption or shopping, and community activities.
\end{abstract}

Keywords-e-Lifestyle; consumer; Generation Z; social media; information technology

\section{INTRODUCTION}

The development of the internet in Indonesia is developing and encouraging digital media in communication or other purposes. Data from the Ministry of Communication and Information of the Republic of Indonesia shows that internet users in Indonesia in 2019 have reached 54 percent or 143 million of Indonesia's 265 million inhabitants. Of these internet users, 80 percent are teenagers aged 15-19 years. For Facebook users, Indonesia is ranked 4th in the world. In one minute, there were 3.3 million information uploaded on Facebook and 2.9 million information spread on WhatsApp every minute from this data. This result is based on UNESCO research concludes that 4 out of 10 Indonesians are active on social media such as Facebook and WhatsApp [1].
Communication technology has facilitated daily life and communication [2] and changing ways and patterns of life that impact product utilization [3]. According to [4], understanding lifestyles is useful in delivering products appropriate to the target segment, especially as a basis for compiling information technology-based marketing on products. Understanding digital-oriented lifestyles (e-lifestyle) helps understand segments of products to be marketed through digital media. For example, [3] uses a digital-oriented lifestyle (e-lifestyle) in analyzing the adoption process of using information technology in banking. [5] managed to identify the avoidance of advertisements in terms of digital lifestyle (e-lifestyle), and [6] examined the relationship of e-lifestyle with perceived corporate identity, consumer satisfaction, and loyalty of cellular service users.

The Indonesian Internet Service Providers Association in 2017 shows that based on age group, 49.52 percent of internet users in Indonesia aged 19 to 34 years who produce new professions in the digital world, that digital-oriented lifestyle is the majority in the $\mathrm{Z}$ generation group. This generation has different characteristics and characteristics from the previous generation, but information about the generation is minimal [7]. Generational understanding is essential because generational boundaries have different ways of thinking, decision making, and behavior that cause problems when there are gaps in understanding across generations. Communication is an essential part of this generation [8], so understanding this generation's lifestyle is essential in the educational, social, and economic context.

Generation $\mathrm{Z}$ is the generation after 1995, which is also called i-generation or post-millennial. Different terms refer to this generation, such as i-Generation, technology generation, online generation, Post Millennials, and Facebook Generation [8]. The differences in each generation bring significant and significant differences in the segmentation of consumer behavior. According to Forrester Research, Generation $\mathrm{Z}$ consumes more online media than offline media and spends 3.9 hours a week watching shows online, compared to all US adults who only spend 1.6 hours a week. According to The Cassandra Intelligence Group Report that studies the habits of Generation Z, more than a third of Generation $\mathrm{Z}$ uses tablets or gadgets regularly, $70 \%$ of ages 10 to 13 carry mobile devices, and $65 \%$ use mobile applications.

Generation $\mathrm{Z}$ has similarities to generation $\mathrm{Y}$ and can apply all activities at once by only using technology. This generation spends much time dealing with cyberspace. This generation is familiar with technology and familiar with digital technology and communication. Experts highlight the fact that Generation $\mathrm{Z}$ can adapt well to the real and virtual 
worlds. This generation can easily switch between two real and virtual because they have the assumption of complementing one another [9]. The consequence of this condition is that part of Generation $\mathrm{Z}$ can easily find and explore the information they need. This generation also quickly shares information with others. The communication processing between these generations is sustainable because it uses various communication devices or social media. This generation is an active social media user with many contacts and has daily relationships through social media channels [10]. Generation $\mathrm{Z}$ uses various mobile devices and likes to assess the reality and the environment around them. This generation embodies their opinions and attitudes using Twitter, blogs, and internet forums and likes to share photos (Instagram, Pinterest, Snapchat) and films (YouTube, Instagram, Snapchat). Generation $\mathrm{Z}$ not only uses Internet content, but they also create and control it [11]. Lifestyle understanding in this group and the media are essential information for all interested parties in designing appropriate communication for this generation.

Lifestyle is an important factor considered in predicting consumer behavior. Lifestyle is a living pattern people who spend time and money on specific activities and are contemporary and comprehensive [12]. Lifestyle describes the whole person who interacts with their environment. Compared to relatively stable values, lifestyles tend to change more quickly. Lifestyle is needed in determining market segments of consumer behavior [13]. Author in [14] stated that lifestyle segmentation measures human activities based on individual patterns of spending time, interests, and points of view of themselves and others according to underlying characteristics, such as income, education, and residence. In predicting consumer behavior, experts argue that individual lifestyles will determine individual consumption behavior. Lifestyle understanding in Generation $\mathrm{Z}$ is expected to provide valuable information in various fields of socio-economic life. Building and validating an electronic lifestyle scale that can describe a more holistic lifestyle for online marketers have received researchers' attention in several countries, such as [15] in Malaysia, [16] in Turkey, and [17] in India. e-Lifestyle is the main focus of this research. In principle, the formulation of the problem is based on confirmation of e-lifestyle factors.

\section{LITERATURE REVIEW}

\section{A. e-Lifestyle}

In the digital age, [18] uses Kelly's construction theory to build a lifestyle scale in the domain of IT adoption. In contrast, [19] uses the theory of human motivation and the value of hope to build a lifestyle instrument for hospitality consumers. Personal construction theory emphasizes human capacity and emotional experience, stating that individuals engage in certain behaviors due to a series of natural consequences [20]. Human motivation theory states that motivation largely contributes to certain behaviors, such as motivation from basic needs, food, hobbies, goals, circumstances, or ideals [19]. Expectancy value theory, which Fishbein developed in the 1970s [21], suggests that people orient themselves to the world following the expectations or beliefs and evaluations of each individual.
In [22], argues that lifestyle is a set of behaviors initiated by motivation, which develops by interacting with environmental conditions and shapes by choices, conditions, cognition, and beliefs. Human motivation theory, expectancyvalue theory, and unique construction theory all originate from sociology and psychology. Therefore, from a sociological perspective, lifestyles are motivated by external stimulants [22]. From a psychological standpoint, [22] suggests that the internal trust initiates lifestyle. The AIO study considers lifestyle as a series of behaviors that reflect individual psychological considerations and sociological consequences. Based on the literature review above, theories related to lifestyle are generally agreed that human behavior can be predicted and explained by the function of psychological and sociological variables.

Psychological and sociological constructions can predict elifestyles. This study uses four constructs that are electronic activities (e-activities), electronic interests (e-interests), electronic opinions, (e- opinion) and electronic values (evalues) to evaluate lifestyle. Lifestyle is a series of behaviors that reflect an individual's psychological problems (internal beliefs) and sociological consequences (external stimuli). This research operationalizes digital or electronic activities as "observable actions" in using services or products supported by information technology, electronic interest as logical tendencies to use services or products supported by information technology, electronic opinion as "fundamental responses" on issues of services or products supported by information technology, and electronic value as basic beliefs about services or products supported by information technology. Specifically, the first three constructs of activitiese, e-opinion, e-interest are based on AIO [14], while, the evalue construct is drawn from the LOV, VALS, and RVS studies [23], [24], [25], [26] designed the lifestyle of 27-item internet users, [27] made 30 statement items to assess the lifestyle of internet users, [28] proposes a 38-item assessment of lifestyle-related to internet use by internet buyers, [29] expanding and replicating the work of [30], [25] adopted 56item China-VALS to survey consumer lifestyles in the mobile market. Several researchers have tested the e-lifestyle construct, such as [16], which measures it based on factors of interest, entertainment, sociability, perceived importance, concern, and novelty. Author in [17] also tested e-lifestyle constructs using the subject of shoppers in India. Previous studies have not examined the $\mathrm{Z}$ generation group, which is the dominant part of the digital era segment.

\section{B. Generation $Z$ and behaviour}

The emergence of theories about generation gave birth to groups of generations X, Y, and Z. Several researchers have tried to understand generational characteristics and study generational differences between groups [31], [32], [33]. Some authors like William Strauss and Neil Howe describe the demographic group with the birth year beginning after the 1980s as the millennial generation written in Generations; The History of America's Future, 1584 to 2069. This generation is referred to as the $\mathrm{Y}$ generation, a continuation of the baby boomer generation or generation $\mathrm{X}$. The change of generation from generation $\mathrm{X}$ to $\mathrm{Y}$ generation carries significant and significant implications, especially in marketing. Some 
literature states that this group numbered more than three times the number of previous generations. Gen $\mathrm{Y}$ is a unique consumer group in decision making, and its behavior is heavily influenced by media technology and information. Marketers need to identify consumer behavior in this group and the media that influence it as a basis for the preparation of segmentation, targeting, and positioning. According to [34], generation $\mathrm{Y}$ is more individualistic but cares about social responses, more educated, intelligent in technology, updated information, and more structured in certain groups. Many companies use event marketing to attract generation $\mathrm{Y}$ by involving the activities of this group community. Author in [35] shows that generation $Y$ loves electronic media such as television and the Internet, and the majority respond to advertisements based on billboard media and shared community media. These behaviors need to be taken into consideration for companies in determining the appropriate media for this generation.

Generation $X$ is a generation before 1980. The generation born between 1980-1995 is called the Y generation, called the millennial generation, and after 1995 is called the $\mathrm{Z}$ generation, called i-generation or post-millennial. The differences in each generation bring significant and significant differences in the segmentation of consumer behavior. According to Forrester, Generation $\mathrm{Z}$ consumes more online media than offline media and spends 3.9 hours a week watching shows online, compared to all US adults who only spend 1.6 hours a week. According to The Cassandra Intelligence Group Report that studies the habits of Generation $\mathrm{Z}$, more than a third of Generation $\mathrm{Z}$ uses tablets or gadgets regularly, $70 \%$ of ages 10 to 13 carry mobile devices, and $65 \%$ use mobile applications.

Generation $\mathrm{Z}$ has similarities to generation $\mathrm{Y}$ and can apply all activities at once by only using technology. This generation spends much time dealing with cyberspace. For example, this group also has a high dependence on smartphones [36]. This generation is familiar with technology and familiar with digital technology and communication. Understanding consumer behavior in this group and the media that influence it considers marketers to design appropriate marketing communications. Socially, Generation $\mathrm{Z}$ values peer groups more and prefers social media in cyberspace. This group is more imaginative, confident, optimistic, and more lateral. Generation $\mathrm{Z}$ likes involvement and efforts to build relationships. Generation $\mathrm{Z}$ has similarities with Generation Y because it is a continuation of Generation $Y$, preferring social media in communication and self-expression. Generation $\mathrm{Z}$ tends to focus on innovation. This generation was born in the era of internet technology and is instant like touch screen media. Technological innovations become the hope for this group to provide comfort for them. This generation is classified as a generation with free choices on products that tend to be influencers for family consumption.

Generation $\mathrm{Z}$ has more power than previous generations to redefine production and consumption [37]. Generation z group is a generation group that is closely related to socially and technologically [38]. Generation $\mathrm{Z}$ stands out from the rest of the generation in at least one aspect that this group has never seen without the Internet [39]. Regarding the behavior of Generation Z, marketers need to involve this generation in building brand equity such as various marketing activities that involve the group directly and build networks for this group through digital social media so that this group feels part of the company. Generation $\mathrm{Z}$ customers are highly customized online, and app shoppers. As Generation Z's purchasing power grows, marketers need to understand how their consumers behave [37]. Marketers must adapt related to the way in sharing information on brands and products that tend to be mobile compared to print media. Marketers can also use digital media to communicate family products through this generation according to their role as influencers for family purchases.

\section{DESIGN METHODOLOGY}

This type of research is a survey. This research was initiated through empirical field observations, also added with environmental data. The research population used in this study is the $\mathrm{Z}$ generation of consumers. This study sample is a group of students who fall into the $\mathrm{Z}$ generation category born after 1995. The sampling technique uses convenience sampling techniques. The data used are primary; that is, the response provided by research subjects related to e-lifestyle. Samples were collected from as many as 427 respondents and met the criteria for analysis. Data was collected through a survey using a closed and open questionnaire. A closed questionnaire was used to identify the e-lifestyle of the respondents using a Likert scale. An open questionnaire is used to explore information about the factors of respondents using information and communication technology. This study's variables are interdependent, namely e-lifestyle variables consisting of four constructs; e-activities, e-interest, e-opinions, and e-values. The indicators of the four constructs as follows in Table I [24] [43].

\section{A. Data Normality Test}

Data normality can be observed through skewness and kurtosis values. Observation can be done by paying attention to the value of $\mathrm{z}$ or $\mathrm{z}$ value. Data is said to be normal if it has a critical value below the $\mathrm{z}$ value. The $\mathrm{z}$ value for the probability of $1 \%$ is \pm 2.58 . Based on the normality test data, it is known that all data derived from e-lifestyle variable data have a critical ratio or critical value below \pm 2.58 .

TABLE I. E-LIFESTYLE CONSTRUCTS

\begin{tabular}{|l|l|l|l|}
\hline e-Activities & e-Interests & e-Opinions & e-Values \\
\hline Work & Family & Themselves & Respected \\
Hobbies & Home & Social issues & Accomplishment \\
Social events & Job & Politics & Fullfilment \\
Vocation & Community & Business & Relationships with \\
Entertainment & Recreation & Economics & others \\
Club & Fashion & Education & Expectation \\
membership & Food & Production & Prejudices \\
Community & Media & Future & Hopes \\
Shopping & Achievements & Culture & Demands \\
Sports & & \multicolumn{2}{|l}{ Sources: Adapted from [24] [43] }
\end{tabular}




\section{B. Test Instrument}

According to [40], validity indicates the accuracy and accuracy of measuring instruments in carrying out their measurement functions. A validity test using factor analysis was performed. The test results show that the KMO value of 0.550 is higher than 0.5 [41], which indicates that the number of samples has fulfilled the sample adequacy rules for further analysis. Validity analysis shows that there are three invalid items with extraction values less than 0.4 [42].

Reliability testing is related to the problem of trust in the instrument. An instrument can have a high level of confidence if testing the instrument shows permanent results. Thus, the instrument reliability problem is related to the problem of the accuracy of the results. This study's reliability analysis uses Cronbach Alpha to identify how well the questionnaire's items are related to one another. The Alpha coefficient obtained ranges from 0.729 to 0.823 greater than 0.7 [42].

\section{Data Analysis Techniques}

Data analysis techniques in this study used factor analysis techniques. The factors formed in the analysis are based on the concept of confirmation using CFA.

\section{RESULT AND DISCUSSION}

\section{A. Result}

Factor analysis can group or reduce the number of similar questions to provide information on whether several questions in one attribute measure the same domain or not. If the same will become one group and, if not, will be separated. The extraction results of the communalities in the variables are presented in Table II. Communality is a measure of the percentage of variation in variables explained by factors. The extreme value of communality is between 0.0 and 1.0 . Estimation of 1.0 means that the variables' variance correlates perfectly with other variables due to several shared factors. For example, ea1 (factor 1 ) is 0.444 , which means a factor 1 question or item shows a $44.4 \%$ level of equality with other variables caused by several shared factors. In comparison, the remaining $55.6 \%$ is the uniqueness of that variable, influenced by other factors.

The rotation factor method used is the varimax rotation method, where the results can be seen after six iterations, from Table III, known variable e-lifestyle factors grouping. The results of the rotation factors in Table III confirm four dimensions. Dimension 1 is an e-activities factor; dimension 2 is an e-interests factor; dimension 3 is an e-opinions factor. Dimension 4 is the e-values factor. The results of the rotation component matrix are as follows in Table III.
TABLE II. COMMUNALITIES

\begin{tabular}{|c|c|}
\hline \multicolumn{2}{|c|}{ Communalities } \\
\hline & Extraction \\
\hline ea1 & .444 \\
\hline ea2 & .476 \\
\hline ea3 & .475 \\
\hline ea4 & .491 \\
\hline ea5 & .496 \\
\hline ea6 & .443 \\
\hline ea7 & .520 \\
\hline ea8 & .508 \\
\hline ea9 & .532 \\
\hline ea10 & .520 \\
\hline ei1 & .495 \\
\hline ei2 & .497 \\
\hline ei3 & .623 \\
\hline ei4 & .650 \\
\hline ei5 & .732 \\
\hline ei6 & .695 \\
\hline ei7 & .706 \\
\hline ei8 & .787 \\
\hline ei9 & .776 \\
\hline ei10 & .624 \\
\hline ei11 & .148 \\
\hline ei12 & .106 \\
\hline eo1 & .492 \\
\hline eo2 & .169 \\
\hline eo3 & .552 \\
\hline eo4 & .560 \\
\hline eo5 & .563 \\
\hline eo6 & .582 \\
\hline eo7 & .638 \\
\hline eo8 & .644 \\
\hline eo9 & .595 \\
\hline eo10 & .526 \\
\hline eo11 & .586 \\
\hline eo12 & .649 \\
\hline ev1 & .676 \\
\hline ev2 & .711 \\
\hline ev3 & .728 \\
\hline ev4 & .629 \\
\hline ev5 & .587 \\
\hline ev6 & .588 \\
\hline ev7 & .551 \\
\hline ev8 & .416 \\
\hline ev9 & .465 \\
\hline ev10 & .478 \\
\hline Extra & ncipal C \\
\hline
\end{tabular}

Sources: Data Processed 
TABLE III. COMPONENT MATRIX

\begin{tabular}{|c|c|c|c|c|}
\hline \multicolumn{5}{|c|}{ Component Matrix ${ }^{a}$} \\
\hline & \multicolumn{4}{|c|}{ Component } \\
\hline & 1 & 2 & 3 & 4 \\
\hline ea1 & & & .631 & \\
\hline ea2 & & & .523 & \\
\hline ea3 & & & .518 & \\
\hline ea4 & & & .609 & \\
\hline ea5 & & & .425 & \\
\hline ea6 & & & .568 & \\
\hline ea7 & & & .643 & \\
\hline ea8 & & & .635 & \\
\hline ea9 & & & .634 & \\
\hline ea10 & & & .443 & \\
\hline ei1 & & .673 & & \\
\hline ei2 & & .674 & & \\
\hline ei3 & & .749 & & \\
\hline ei4 & & .773 & & \\
\hline ei5 & & .825 & & \\
\hline ei6 & & .818 & & \\
\hline ei7 & & .829 & & \\
\hline ei8 & & .872 & & \\
\hline ei9 & & .862 & & \\
\hline ei10 & & .783 & & \\
\hline eo1 & .456 & & & \\
\hline eo2 & .392 & & & \\
\hline eo3 & .408 & & & \\
\hline eo4 & .462 & & & \\
\hline eo5 & .507 & & & \\
\hline eo6 & .602 & & & \\
\hline eo7 & .592 & & & \\
\hline eo8 & .631 & & & \\
\hline eo9 & .599 & & & \\
\hline eo10 & .612 & & & \\
\hline ev1 & . & & & 402 \\
\hline ev2 & & & & .449 \\
\hline ev3 & & & & .842 \\
\hline ev4 & & & & .786 \\
\hline ev5 & & & & .512 \\
\hline ev6 & & & & .453 \\
\hline ev7 & & & & .473 \\
\hline ev8 & & & & .525 \\
\hline ev9 & & & & .629 \\
\hline ev10 & & & & .610 \\
\hline \multicolumn{5}{|c|}{ Extraction Method: Principal Component Analysis. } \\
\hline a. $4 \mathrm{co}$ & ents ex & & & \\
\hline
\end{tabular}

Sources: Data Processed

\section{B. Qualitative Analysis}

Qualitative analysis is used to identify the factors of respondents using information and communication technology. In general, students use information and communication technology daily with considerations, namely:

1) Social media communication: Students use information and communication technology intending to communicate actively or passively in social media. Some excerpts from student opinions are as follows:

"... to see info from Instxxxxm ..."

"... everyday for Youxxbe access ..."

"... look for trends or those that are viral ..."

'... make it exist..update in ..."

The communication carried out also aims to update/upload information from individual activities, a form of selfactualization. Some excerpts from student opinions are as follows:

"... to upload photos ... videos of precious moments ..."

"... self-actualization ... seen ... seeing ..."

Information about social media that are often used by Generation $\mathrm{Z}$ with the highest to lowest ranking; Instagram, YouTube, Line, Facebook, Twitter, Discard, Pinterest, Spotify, and Telegram. Some excerpts from student opinions are as follows:

"... info on Instagram ..."

"..Video..youtube .."

"..Chat use the line ..."

"..Update..info..facebook .."

"... communication ... news friends ... Twitter .."

"... discard ..."

"... Pinterest ..."

"..Spotify ... sometimes telegrams ..."

2) Entertainment: Students use information and communication technology with the aim of entertainment. Some excerpts from student opinions are as follows:

"... listen to music ..."

".. watch..movie .."

"..Game .."

"... Information of fashion ..."

3) Shopping or consumption: Students use information and communication technology with the aim of consumption/shopping. Some excerpts from student opinions are as follows:

".. make buying goods ... online ..."

"... the need to see products that are more trendy ..."

"... transactions to buy goods ..."

"... order goods ..."

4) Community or hobby: Students use information and communication technology as a means to form a community or a shared hobby. Some excerpts from student opinions are as follows:

"..For a group of hobbies ..."

"... community ... the same ..." 


\section{Discussion}

Generation $\mathrm{Z}$ is a generation close to technology [37] and cannot be separated from the internet [38]. Generation $\mathrm{Z}$ has a lifestyle supported by various mobile devices and likes to assess the reality and the surrounding environment. These findings are also consistent with the findings that most of this generation uses technology for communication, entertainment, hobbies, and consumption purposes. Information media is used as a medium to find information. This generation embodies their opinions and attitudes using media such as Twitter, blogs, and internet forums and likes to share photos (Instagram, Pinterest, Snapchat) and films (YouTube, Instagram, Snapchat) as part of communication. This generation not only uses Internet content but is also involved in creating and controlling information technology. Author in [39] explains that four constructs can be used in measuring elifestyle combined from AIO, VALS, ROV, and LOV, namely; e-activities, e-interests, e-opinions, and e-values. Digital-oriented lifestyles can be identified through a) eactivities in the form of actions that can be observed in using services or products supported by information technology including work, hobbies, social activities, entertainment, sports, b) e-interest in the form of logical tendencies in using services or products supported by information technology include work demands, family, community, and available media factors, c) e-opinion as a fundamental response to the problems of services or products supported by information technology including social, economic, political and educational needs, and d) e-values in the form of fundamental beliefs about services or products supported by information technology including expectations, needs, relationships with fellow individuals, and requests.

Following the construct combined from AIO, VALS, $\mathrm{ROV}$, and LOV, Generation $\mathrm{Z}$ has a lifestyle following elifestyle. This study's results follow the validation of [44], who used the formative first-order and second-order hierarchical latent constructs. The finding of this research confirmation contributes to the body of knowledge regarding e-lifestyle measurement in Generation Z. According to the $\mathrm{Z}$ generation group, which is consistent with the use of digital technology, e-lifestyle shows the form of activities that this generation does daily. Generation Z's lifestyle relies heavily on digital devices, internet services available, and innovative digital products for entertainment, interpersonal relationships, social networking, economic transactions, and the overall gathering of information and knowledge [45].

\section{CONCLUSION}

Based on the results of the analysis and discussion, it can be concluded that motives of e-lifestyle in Generation Z, primarily among students, are formed in four factors: eactivities, e-interests, e-opinions, and e-values. Digitaloriented lifestyles can be identified through e-activities in the form of actions that can be observed using services or products supported by information technology, including work, hobbies, social activities, entertainment, and sports. eInterest in the form of logical tendencies in using services or products supported by information technology include work demands, family, community, and available media factors, e- opinion as a fundamental response to the problems of services or products supported by information technology including social, economic, political and educational needs, and e-values in the form of fundamental beliefs about services or products supported by information technology including expectations, needs, relationships with fellow individuals, and requests. Information or social media are often used by Generation Z, namely Instagram, Youtube, Line, Facebook, Twitter, Discard, Pinterest, Spotify, and Telegram. Using information or social media is communication, entertainment, consumption or shopping, and community or hobby activities. The findings are generally expected to be used as materials for planning strategies related to lifestyles in the digital age and patterns of shaping behavior from e-lifestyle to be a part of consumer education and socialization. According to the media, socialization and education activities can use digital or media information technology often used by Generation Z.

This research does not classify the gender aspects of the subject or Generation Z, even though it is likely that there will be differences in behavior by gender [46]. Future studies can consider gender aspects in analyzing e-lifestyle in this generation. Another possibility is that this generation group will adapt quickly to possible future behavior changes, so the longitudinal analysis is needed. Besides, further research can consider other e-lifestyle measurement models such as LOV, and RVS studies [23] [24].

\section{ACKNOWLEDGMENT}

The authors would like to thank Institute of Research and Community Service-UNY which funded this research.

[2] Hassan, S, H, Thurasamy, T, R, and Lio, W, Y, "E-lifestyle, customer satisfaction and loyalty among mobile subscribers in Thailand," International Review of Management and Marketing, Vol 7 (1), 354362, 2017.

[3] Yu, C, S, "Using E-lifestyle to Analyze Mobile Banking Adopters and non-Adopters," Journal of Global Information Technology Management, Vol 18, pp.188-213, 2015.

[4] Chen, T.Y, and He, Q.Y, "Applying decision tree techniques to segmentation bases for e-marketing, Management Science Research". 3(1), pp.1-25, 2006.

[5] Koshksaray, A, A, Franklin, D, and Hanzaee, K, H, "The relationship between e-lifestyle and internet advertising avoidance," Australasian Marketing Journal. Vol 23. No 1.2015.

[6] Hassan, S, H., Yee, L, W, and Thurasamy, R, "Consumer e-lifestyle, perceived corporate identity, customer sat isfaction and loyalty among young mobile service suscribers: A cross cultural examination of Indonesia-Malaysia-Thailand growth triangle (IMT-GT)". International Journal of Management and Applied Science Journal. Vol 2.(7), 2016.

[7] Singh, A, P, and Dangmai, J, "Understanding the generation Z: The future workforce," South-Asian Journal of Multidisicplinary Studies. Vol 3. No 3, 2016.

[8] Dolot, A, "The characteristic of generation Z," E-mentor. Vol 2. No 74, 2019.

[9] Żarczyńska-Dobiesz, A, \& Chomątowska, B, "Pokolenie Z na rynku pracy - wyzwania dla zarządzania zasobami ludzkimi," Prace Naukowe Uniwersytetu Ekonomicznego we Wrocławiu, Vol 350, pp.405-415, 2014.

[10] Csobanka, Z.E, "The Z Generation," Acta Technologica Dubnicae, Vol 6(2), pp.63-76, 2016.

[11] Hardey, M, "Generation C: Content, creation, connections and choice," International Journal of Market Research, Vol 53(6), pp.749-770, 2011. 
[12] Engel, J.F, Roger, D.B, and Paul, W. M, Consumer behavior. International Edition, Forth Worth : Dreyden Press, 2000.

[13] Suprapto, B, and Wijaya, T, "Intention of Indonsian consumers on buying organic food," International Journal of Trade, Economics, and Finance, Vol 3. No 2, 2012.

[14] Plummer, J.T, "The concept and application of life style segmentation," Journal of Marketing, Vol. 38 No. 1, pp. 33-7, 1974.

[15] Ahmad, N, Omar, A, and Ramayah, T, "Examining the validity and reliability of e-lifestyles scale in the Malaysian context: Preliminary results". In 3rd International Conference on Technology and Operations Management (ICTOM2012), 4th-6th July 2012.

[16] Mend1, B, and Mendı, O, "Evaluation of Validity and Reliability of the Turkish Version of the E-lifestyle Instrument," Journal of Yaşar University. Vol 10 No. 4, pp. 6624-6632, 2015.

[17] Pandey, S, and Chawla, D, "E-lifestyles of Indian online shoppers: A scale validation," Journal of Retailing and Consumer Services, Vol. 21 Issue 6, pp. 1068-1074, 2014.

[18] Malhotra, Y, "Bringing the adopter back into the adoption process: a personal construction framework of information technology adoption," The Journal of High Technology Management Research, Vol. 10 No. 1, pp. 79-104, 1999.

[19] Lin, F.Y, An analysis of hospitality consumer lifestyles in the United States" PhD dissertation, Texas Tech University, Lubbock, TX, 2003.

[20] Neimeyer, R.A, and Neimeyer, G.J, Advances in Personal Construct Psychology, 5th ed.,Praeger, New York, NY, 2002.

[21] Ajzen, I, and Fishbein, M, Understanding attitude and predicting social behavior. Englewood Cliff, New York : Prectice Hall, 1980.

[22] Walters, G.D, Lifestyle Theory: Past, Present, and Future, Nova Science Publishers,Commack, NY, 2006.

[23] Roy, S, and Goswami, P, "Structural equation modeling of valuepsychographic trait-clothing purchase behavior: a study on the urban college-goers of India", Young Consumers, Vol. 8 No. 4, pp. 269-277, 2007.

[24] Harcar, T, and Kaynak, E, Lifestyle orientation of rural US and Canadian consumers, Asia Pacific Journal of Marketing and Logistics, Vol. 20 No. 4, pp. 433-454, 2008.

[25] Zhu, H, Wang, Q, Yan, L, and Wu, G, "Are consumers what they consume? Linking lifestyle segmentation to product attributes: an exploratory study of the Chinese mobile phone market," Journal of Marketing Management, Vol. 25 No. 3. 295-314, 2009.

[26] Kim, K.H, Park, J.Y, Kim, D.Y, and Moon, H.I, "Internet user lifestyle: its impact on the effectiveness of internet advertising in Korea", Conference, American Academy of Advertising, Salt Lake City, UT, USA, 2001.

[27] Yang, K.C.C, "A comparison of attitudes towards internet advertising among lifestyle segments in Taiwan," Journal of Marketing Communications, Vol. 10 No. 1, pp. 195-212, 2004.

[28] Brengman, M., Genuens, M., Weijters, B, Smith, S.M, and Swinyard, W.R, "Segmenting internet shoppers based on their web-usage-related lifestyles: a cross-cultural validation," Journal of Business Research, Vol. 58, pp. 79-88, 2005.

[29] Allred, C.R, Smith, S.M, and Swinyard, W.R, "E-shopping lovers and fearful conservatives: a market segmentation analysis," International
Journal of Retail \& Distribution Management, Vol. 34 No. 4, pp. 30833, 2006.

[30] Swinyard, W.R, and Smith, S.M, "Why people (don't) shop online: a lifestyle study of the internet consumer," Psychology \& Marketing, Vol. 20 No. 7, pp. 567-97, 2003.

[31] Lazanyi, K, and Bilan, $Y$, "Generetion $\mathrm{Z}$ on the labourmarket-do they trust others within their workplace?" Polish Journal of Management Studies. Vol. 16 No. 1, pp. 78-93, 2017.

[32] Lanier, K, "5 Things HR professionals need to know about generation Z: thought leaders share their views on the HR profession and its direction for the future," Strategic HR Review. Vol. 16 No. 6, pp. 288-290, 2017.

[33] Grow, J.M, and Yang, S, "Generation-Z enters the advertising workplace: expectations through a gendered lens," Journal of Advertising Education. Vol. 22 No. 1, pp. 7-22, 2018.

[34] Syrett, M, and Lammiman, J, "Advertising and millennials," Young Consumers. Vol 5. No 4. 62-73, 2004.

[35] Valentine, D, B, and Powers, T, L, "Generation Y values and lifestyle segments," Journal of Consumer Marketing, Vol. 30 No. 7, pp. 597-606, 2013. https://doi.org/10.1108/JCM-07-2013-0650.

[36] Bukhori, B, Said, H., Wijaya, T., and Nor, F, M. "The Effect of Smartphone Addiction, Achievement Motivation, and Textbook Reading Intensity on Students' Academic Achievement," iJIM. Vol. 13, No. 9, 2019. doi.org/10.3991/ijim.v13i09.9566.

[37] Priporas, C-V, Stylos, N, and Fotiadis, A, K, "Generation Z consumers' expectations of interactions in smart retailing: A future agenda," Computers in Human Behavior. Vol 77. 2017.

[38] Turner, A, "Generation Z: Technology and Social Interest," The Journal of Individual Psychology Vol 71 No. 2, pp. 103-113, 2015. doi:10.1353/jip.2015.0021.

[39] Chillakuri, B, "Understanding Generation Z expectations for effective onboarding," Journal of Organizational Change Management, Vol. ahead-of-print No. ahead-of-print., 2020. https://doi.org/10.1108/JOCM02-2020-0058.

[40] Sekaran, U, Research methods for business: Skill-building approach, Fourth Ed, New York : John Wiley \& Sons Inc, 2003.

[41] Gie, Y, A, and Pearce, S, "A beginner's guide to factor analysis: Focusing on exploratory factor analysis," Tutor Quant Methods Psychol. Vol 9, pp. 79-94, 2013.

[42] Hair, J.F, Black, B, Babin, B, Anderson, R, E, and Tatham, R. L, Multivariate data analysis, 6th Ed, New Jersey: Prentice Hall International, Inc, 2006.

[43] Yu, C, S, "Construction and validation of an E-lifestyle instrument," Internet Research, Vol 21(3), pp.214-235, 2011.

[44] Hassan, S, H, Ramayah, T, Mohamed, O, and Maghsoudi, A, "Elifestyle conceptualization: Measurement model validation using variance based structural equation modeling (SEM-PLS)," Modern Applied Science, Vol 9 (2), pp.319-332, 2015.

[45] Hoque, A. S. M. M, "Digital device addiction effect on lifestyle of geeration Z in Bangladesh," Asian People Journal (APJ), 1(2), pp.21-44, 2018.

[46] Kraljević, R, and Filipović, Z, "Gender Differences and Consumer Behavior of Millennials", Acta Economica Et Turistica, Vol 3 No. 1, pp. 5-13. 2017. doi: https://doi.org/10.1515/aet-2017-0002. 